\title{
Establishing a Fiscal Dialogue in Europe
}

\author{
Jérôme Creel ${ }^{1}[0$
}

Accepted: 19 February 2021 / Published online: 15 March 2021

(c) Association for Comparative Economic Studies 2021

\begin{abstract}
In this contribution, I use the fiscal theory of the price level as a backdrop for a discussion on the risks that expansionary fiscal policies may pose on debt sustainability. I recall that a regime of fiscal dominance does not lead to macroeconomic instability. I also review a few empirical papers on fiscal sustainability and I conclude, also based upon own estimates, that it is not a major concern, at least in the short to mid-run. Finally, I argue that Europeans should continue on the fiscal impetus they contributed to in 2020 by fostering coordination and transparency on EU fiscal policies. To achieve this objective, I revisit the idea of an enhanced dialogue on fiscal matters at the European Parliament and propose to establish a Fiscal Dialogue with the EU Member States.
\end{abstract}

Keywords Fiscal policy $\cdot$ Public debt $\cdot$ Fiscal governance $\cdot$ European Union

JEL Classification E62 $\cdot \mathrm{F} 42 \cdot \mathrm{H} 60 \cdot \mathrm{H} 61 \cdot \mathrm{H} 63$

\section{Introduction}

Covid-19 crisis gave rise to exceptional fiscal responses by European Union (EU) governments that have culminated with the adoption of a common recovery plan labelled Next Generation EU. This plan is the outcome of a momentum of coordinated fiscal decisions between EU governments, the European Commission and

\footnotetext{
This paper is based on a keynote speech given at the 8th UECE Conference on Economic and Financial Adjustments in Europe, ISEG, Lisbon, on 27 November 2020 and entitled "Fiscal policy, the 'new' fashion". I wish to express my gratitude to Antonio Afonso for his kind invitation and for pushing me to prepare the talk and paper. I do also thank the participants for their questions and remarks during the conference and among them, Ana Sofia Pessoa and Ludger Schuknecht. I am also grateful to Georg Feigl, Dario Paternoster, Drazen Rakic, Francesco Saraceno and Achim Truger for their comments on a very preliminary draft. The usual disclaimer applies.
}

Jérôme Creel

jerome.creel@sciencespo.fr

1 Research Dpt (OFCE) and LEH Dept (ESCP), Sciences Po-OFCE and ESCP Business School, Paris, France 
Table 1 Annual variation in the primary balance, in absolute value expressed in percentage points of GDP. Source: AMECO database (data uploaded on 18 December 2020), author's computations

\begin{tabular}{lllll}
\hline & EU & Euro area & US & Japan \\
\hline $2020 *$ & 7.9 & 8.2 & 8.0 & 10.4 \\
$1996-2019$ & & & & \\
Mean & 0.8 & 0.8 & 1.5 & 1.5 \\
SD & 1.0 & 1.0 & 1.3 & 1.6 \\
Max** $^{*}$ & 4.1 & 4.2 & 5.5 & 6.6 \\
\hline
\end{tabular}

*All values refer to shifts towards fiscal expansion

**All maximum variations were shifts towards fiscal expansion

the European Parliament. Meanwhile, concerns about debt sustainability have also arisen and they may tend to reverse the fiscal stance. In this contribution, I use the Fiscal theory of the price level as a backdrop for a discussion on the risks that expansionary fiscal policies may pose on debt sustainability. I recall that a regime of fiscal dominance does not lead to macroeconomic instability. I also review a few empirical papers on fiscal sustainability and I conclude, also based upon own estimates, that it is not a major concern, at least in the short to mid-run. Finally, I argue that Europeans should continue on the fiscal impetus they contributed to in 2020 by fostering coordination and transparency on EU fiscal policies. To achieve this objective, I revisit the idea of an enhanced dialogue on fiscal matters at the European Parliament and propose to establish a Fiscal Dialogue with the EU Member States.

How exceptional fiscal responses to the Covid-19 crisis have been can be contemplated in Table 1. Fast-growing fiscal deficits have contrasted with slower moves towards either consolidation or expansion that had been usual over two decades. The change in the primary balance between two consecutive years has never been that large in absolute value and in contrast with the mean and standard deviation between 1995 and 2019, the expansionary shift of 2020 seems gigantic. While it is fair to say that part of this change can be attributed to the historical drop in GDP, year 2020 may be the starting point of a new era during which fiscal policy will be the "only game in town", an expression that had been formerly associated with unconventional monetary policies (see Wolf 2012; El Erian 2017).

There are many possible reasons behind the renewed use of fiscal tools, including a reappraisal of fiscal policy. First, the intensive use of monetary policy to cope with the crises may have reduced its ammunitions. In a low rate environment, monetary policy has limited margins of manoeuvre, whereas those of fiscal policy tend to increase (Blanchard and Summers 2020). Second, governments or central banks may have turned towards a regime of fiscal dominance conducive to a strategic shift in their interactions: fiscal policy may act first, whereas monetary policy would follow in a Stackelberg-game approach. The achievement of the objectives of the former would then weigh on the achievement of the latter's. Stated differently, monetary policy may embrace States' objectives and adapt its policies to their achievements ${ }^{1}$.

\footnotetext{
1 One might see recent statements by ECB President, Christine Lagarde (e.g. "I want to explore every avenue available in order to combat climate change", Financial Times, 7 July 2020), as a step in this direction, while a recent ECB working paper on a new orientation of monetary policy towards structural
} 
Third, reliance on fiscal policy beyond the fiscal limits that exist in, e.g. the European Union (EU), may reveal a lack of satisfaction with the fiscal framework. Fiscal rules may have appeared as inappropriate or inefficient. They have not prevented the rise in public indebtedness in a positive interest rate environment and they have become unnecessary to curb debt to GDP ratios with interest rates below the GDP growth rate (Blanchard et al. 2020). Fourth, after decades of criticisms against fiscal policy, its stabilizing properties during recessions have been positively reassessed (Auerbach and Gorodnichenko 2012; Creel et al. 2011).

Finally, the rise in deficits and debts during Covid-19 crisis may have not resulted from a reappraisal of fiscal policy but from a lack of an alternative ${ }^{2}$. Actually, governments reacted swiftly to compensate households and firms for the loss incurred by health measures like lockdowns, but they may have done so under assumptions of low fiscal multipliers. Low appraisal of fiscal policy may therefore imply a quick reversal in policies after the Covid-19 crisis.

Whatever the reasons, good (reappraisal) or bad (TINA), for which fiscal policy has become the 'new' fashion, the same questions arise: will it be sufficient and stabilizing? Will public finance remain sustainable? And what kind of governance will help give positive answers to the first two questions? While appealing, these questions cannot be answered easily. Covid-19 crisis has produced so much uncertainty that the use of pre-Covid analytical tools might be a poor predictor of the future. However, episodes of large increases in debt and deficits are not entirely new, so that macroeconomics is equipped with theories and empirical evidence to shed light on the consequences of fiscal policy on the economy and on the influence of the economy on the behaviour of policymakers.

In the following, I will mainly focus on long-run issues and on the last two abovementioned questions. I will pay less attention to the fiscal multiplier effect, hence to the stabilizing properties of fiscal policy. I will take the results by Gechert and Rannenberg (2018) for granted ${ }^{3}$. In their meta-analyses, they notably show that fiscal tools like transfers and public investment have had high multiplier effects. Fiscal stimuli drawing on these two tools should be a priority then.

I will turn to the consequences of fiscal policy on debt dynamics, and then on the fiscal reactions of policymakers to debt dynamics and the economy. While the effectiveness of fiscal policy to dampen the crisis is of utmost importance, reassuring on debt sustainability even if effectiveness is not achieved immediately is also important to convince that fiscal policy deserves a long-lasting try. I will discuss debt sustainability in the context of fiscal dominance. I will then discuss about fiscal governance and about combating the rise of discontent vis-à-vis politicians and elites (i.e. populism) by enhanced accountability and control of fiscal policies. In

\footnotetext{
Footnote 1 (continued)

objectives like climate change mitigation acts as a kind of confirmation in this regard (Ferrari and Nispi Landi 2020).

2 The application of "There Is No Alternative" (TINA) to a situation of rising deficits and debts would be ironical, as TINA has been coined for the reverse situation: fiscal consolidation, despite its negative real effects.

3 See also Constancio (2020).
} 
this respect and in the context of the EU, I will advocate enhanced accountability vis-à-vis genuinely European democratic bodies, and I will propose to enforce a Fiscal Dialogue between governments and the European Parliament (EP).

\section{Fiscal Dominance in Retrospect}

\section{Theory}

The rise in debt to GDP ratios since the global financial crisis, and its acceleration after the Covid-19 crisis, has raised concerns on the ability of governments to service and pay back their debts ${ }^{4}$ and on the ability of central banks to maintain their independence. The situation resembles the game-theoretic approach developed by Sargent and Wallace (1981) when they argued upon the proper timing and stance of monetary policy when public debt goes adrift. Central bank may not have to accommodate the rise of public debt if and only if fiscal policy turns restrictive, but it will have to accommodate if the government does not diverge from its predetermined fiscal expansion. In this latter case, the later monetary policy will accommodate, the higher the resulting inflation rate. Sargent and Wallace (1981) depict a "chicken game" in which one of the two players must abandon its predetermined behaviour, otherwise public debt will explode. Monetary dominance prevails when fiscal policy shifts towards consolidation, whereas fiscal dominance prevails when monetary policy shifts towards accommodation.

Later on, the fiscal theory of the price level (FTPL) has shed light on the interactions between monetary and fiscal policies and their impact on the price level. More importantly, the theory depicts the price outcomes of a non-Ricardian regime where the government decides upon a fiscal expansion without planning its future primary surpluses (Woodford 1995). The FTPL argues that the government present value budget constraint (PVBC) will hold regardless of the government's behaviour and that the price level may jump to fulfil the government PVBC. Market clearing and the fulfilment by households of their transversality condition will be sufficient for the government PVBC to hold. This result has important implications on the interactions between monetary and fiscal policies (Leeper 1991; Sims 1994). Following Leeper's terminology, monetary policy can be either active (it reacts strongly to inflation) or passive (it does not react strongly to inflation). Fiscal policy can be either active (it does not react strongly to public debt) or passive (it reacts strongly to public debt). A FTPL equilibrium will arise when monetary policy is passive and fiscal policy active, thus fiscal dominance. Monetary dominance is a situation of active monetary policy and passive fiscal policy.

A major importance of the FTPL, and then of fiscal dominance, for policy debates is the reliance on a general equilibrium setting. Far from inducing deviations from the long-run real equilibrium of the economy, if such an equilibrium exists, the FTPL points to the market forces that will ensure public debt sustainability. This

\footnotetext{
${ }^{4}$ Or to roll over their debts at low interest rates.
}

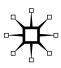


conclusion is certainly model-dependent, but detractors of fiscal expansion also usually rely on a general equilibrium setting to show that it may produce debt unsustainability. The FTPL contradicts this latter view, and without even assuming that fiscal policy may pay for itself via, e.g. a large Christ (1968)'s fiscal multiplier effect. In theory, fiscal expansion will not generate a debt explosion unless monetary policy never alleviates the burden.

Actually, in an environment of interest rates below the economic growth rate, governments can fulfil their PVBC without having to plan future primary surpluses, regardless of monetary policy reaction. The FTPL would just be a theoretical curiosity then. This statement is misleading according to Brunnermeier et al. (2020). They show that insofar as public debt is used to ensure against idiosyncratic shocks, governments can finance government spending without having to raise taxes in the future, a result consistent with the FTPL, and that the risk-free rate on government bonds may well stay below the real economic growth rate. In contrast, the expected return on capital would exceed the real economic growth rate because agents would require a risk premium. It therefore appears that a fiscal theory of the price level "with a bubble" is sufficient to make the FTPL more than a curiosity.

\section{Empirical Evidence}

If the FTPL can be granted some theoretical validity whatever the financial environment (with the risk-free interest rate above or below the real growth rate), its empirical validity remains scarce. Not only is debt sustainability always achieved in theory (unless monetary policy does never accommodate), fiscal dominance is also a very rare event.

The first attempt to test the FTPL is Canzoneri et al. (2001). Drawing on the prediction that in a FTPL regime, a positive shock on the primary surplus to GDP ratio should reduce the price level and raise the debt to GDP ratio, they use a VAR model of the primary surplus and debt to shed light on the relevance of the theory in the US. They show that a positive shock on the primary surplus produces a debt decline that they interpret as a rejection of the FTPL. Creel and Le Bihan (2006) extended the analysis to European countries and overcame the "observational equivalence" put forth by Cochrane (1998) by the use of primary cyclical and cyclically adjusted surpluses. They confirmed Canzoneri et al. (2001)'s conclusion.

Considering the recent surge in deficits and debts, I have updated the analysis on French annual data. The sample goes from 1977 to 2021. The data for the primary surplus to GDP come from the Ameco database, whereas the data for the debt to GDP ratio come from the World Bank Fiscal Space database. Both data series have been updated to the year 2019. Data for 2020 and 2021 come from the French Law of Finance 2021, released by the end of September 2020. I follow the approach proposed by Canzoneri et al. (2001) and focus on the impulse response functions (IRF) of a bivariate, unrestricted VAR-in-level, for surplus and debt expressed in percent of GDP. Both hypotheses, FTPL vs. a "Ricardian" regime, convey the same prediction in the long run: debt sustainability. They differ, however, in terms of their shortrun properties that the IRF will highlight. Under a FTPL regime, the surplus is an 
Response to Cholesky One S.D. (d.f. adjusted) Innovations \pm 2 S.E.

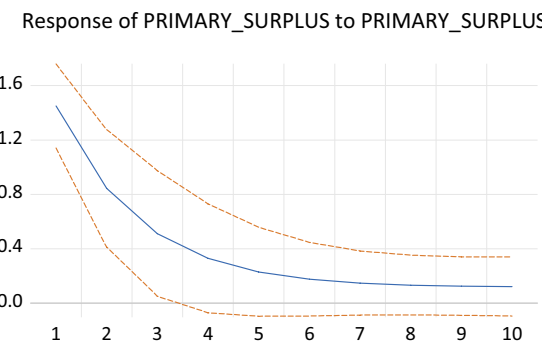

Response of GROSS_DEBT to PRIMARY_SURPLUS

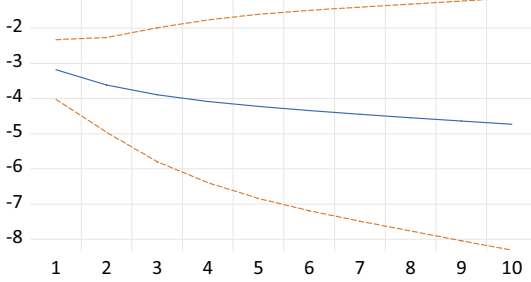

Figure 1 Impulse response functions to a surplus shock, France. Sources: Ameco, World Bank, French Law of Finance 2021, author's estimation

exogenous forcing process. Given that surplus, shocks are plausibly autocorrelated, and that in a FTPL set-up the debt to GDP ratio can jump, the response of debt to a surplus shock is expected to be positive in this regime.

Updated results are reported in Fig. 1. They show that a positive shock on the primary surplus produces a reduction in the debt to GDP ratio. This can be interpreted as a rejection of the FTPL and confirms earlier results by Creel and Le Bihan (2006) on the sample 1963-2001 that a Ricardian regime has been in place in France. The negative relation between surplus and debt is robust to sample changes (removing the most recent years, ending the sample before the global financial crisis, starting the sample after the adoption of the euro, etc.) and to the use of Bayesian VARs (with Minnesota priors) ${ }^{5}$.

Ahmed et al. (2021) take a different view to estimate possible episodes of fiscal dominance. They focus on the monetary reaction function and the impact of public debt. When the latter is growing, they wonder whether monetary policy becomes (more) accommodative. They study developed and emerging market economies and distinguish inflation targeting countries from non-inflation targeting ones between 2000 and 2017 (with quarterly data). They reach the conclusion that "possible" fiscal dominance is limited to emerging countries that do not target inflation, mostly those targeting the exchange rate and having a larger composition of debt denominated in foreign currency. In most cases then, fiscal dominance can be rejected.

Fiscal dominance and FTPL are both consistent with debt sustainability; thus, they are not helpful at discriminating between sustainable and unsustainable episodes. Tests of debt sustainability usually involve estimations of fiscal reactions in the vein of Bohn (1998). If the reaction of the primary (cyclically adjusted) surplus to debt is sufficiently high, debt is sustainable. The literature on fiscal reaction functions has taken different views over the years: using ex-post (revised) data (e.g. Checherita-Westphal and Zdarek 2017), using revised and ex-ante (real-time) data (e.g. Poghosyan and Tosun 2019), or using real-time data (e.g. Cimadomo 2012; Beetsma and Giuliodori 2010). They also permitted to assess whether fiscal policy was counter-, pro- or a-cyclical.

\footnotetext{
${ }^{5}$ Results are available upon request.
} 
Recently, Pierre Aldama and I (Aldama and Creel 2020) followed the vein of Cimadomo (2012) and estimated real-time fiscal reaction functions for a panel of OECD countries. We use vintages of the OECD Outlooks from 1996 to 2017 (December editions) and choose the cyclically adjusted primary surplus as the dependent variable. We conclude that debt sustainability was always achieved between 1997 and 2018: governments used their fiscal instruments to dampen public debt variations in real time. The result is robust to the choice of the estimator (LeastSquare Dummy Variable or Instrument Variable/General Method of Moment), to the group of countries (OECD or euro area countries), and to non-linearities (introduction of interaction terms related to either positive or non-positive output gaps). Finally, we also show that governments develop an asymmetric reaction towards the output gap in real terms: while they do not react to positive output gaps, they tend to implement procyclical policies when the output gap is negative. This is an important result in the European context. Considering the review of the EU fiscal framework that has been under way since February 2020, these results push for a revision of the fiscal rules in favour of more counter-cyclicality, leaving aside the issue of debt sustainability that has seemingly been fixed since (at least) the adoption of the euro.

From all the former developments, it can be concluded that fiscal dominance is a theoretical outcome that may arise in a stable macroeconomic environment, i.e. in a general equilibrium. Moreover, the empirical validity of fiscal dominance has been scarce so far and debt sustainability achieved. Worries about the rise in public debts should not be overstated.

\section{EU Fiscal Governance: Time for Change?}

\section{From Fiscal Rules to Fiscal Standards}

The establishment of fiscal rules in the EU has proceeded along three main economic arguments: the "crowding-out" effect, fiscal policy ineffectiveness and monetary dominance ${ }^{6}$. However, persisting low interest rates ${ }^{7}$ have important implications

\footnotetext{
${ }^{6}$ First, the "crowding-out" effect refers to the impact of rising debts on sovereign yields that would diffuse to long-term interest rates and limit private investment. In a monetary union where only one country would stimulate its economy, higher interest rates would spill over to the rest of the union and hinder private investment in the entire union. This would create a negative externality that fiscal rules should prevent. Second, before its reappraisal, fiscal policy has long been viewed as ineffective, if not useless. The paper by Blanchard and Perotti (2002) may be some kind of a cornerstone in this respect as its motivation stemmed from the willingness to reconcile opposite views about fiscal policy, the ancient vs the modern. The ancient view was embedded in macroeconometric models before DSGE models, assuming or concluding that fiscal policy may be effective, whereas the modern view was discussed in "mainstream" circles (at the time), assuming or concluding that fiscal policy was ineffective. Blanchard and Perotti (2002) concluded that US tax policy had a significant impact on the output and they raised a wave of interest for the effectiveness of fiscal policy that had been absent from academic debates, except of course in (Post-)Keynesian circles, for decades. Third, the monetary dominance argument stemmed from the requirement to firmly establish the independence of the European Central Bank and prevent interferences with the States.

7 The decline in long-term interest rates started before the financial crisis, continued after it and was widespread across countries, irrespective of their cyclical position and has been observed at all maturities. It has accompanied the decline in the natural rate of interest for the past 25 years (see Holston et al. 2017).
} 
for fiscal policy that go against these arguments and dismiss the requirement for fiscal rules.

Actually, fiscal policy becomes an essential tool to maximize employment, activity and preserve financial stability: in a low interest rate environment, active fiscal policy may have a stabilizing effect because it may raise GDP more than debt and interest payments. Moreover, in a world of low interest rates, debt and deficit concerns should be reconsidered. First, the usual crowding-out argument for private / public investment is less warranted. Second, the debt to GDP ratio becomes a misleading concept of fiscal sustainability as the present value of GDP has risen and debt services costs have fallen due to the decline in interest rates; hence, borrowing to finance appropriate categories of government expenditure pays for itself in budgetary terms on reasonable assumptions on interest rates (developments). Finally, fiscal rules were not successful at preventing large debt increases during a positive interest rate era. Although interest rates may stay long below economic growth rates, a situation for which debt sustainability is easily achieved, the situation might revert. Indeed, unless ECB monetary policy remains accommodative for long and has sufficient rooms for manoeuvre, some countries in the euro area may see their sovereign yields depart from those of Germany if spreads rise again. Therefore, debt sustainability may remain an issue but it depends less on deficit and debt levels than on macroeconomic and political uncertainty (Blanchard et al. 2020).

Consequently, Blanchard et al. (2020) have recently argued for a bold reform of the EU fiscal framework with the adoption of "enforceable fiscal standards", hence "a statement of general objectives, coupled with a process for assessing whether member policies meet the standard which draws on all relevant information". They go on and state that "unlike rules, standards distinguish good behaviour from bad behaviour in qualitative rather than numerical terms. Whether the standard is satisfied is determined ex-post, at the point of application. This allows an adjudicator to draw on a much larger set of information than typically enters rules. It also allows room for judgment". Their proposal finally rests on stochastic debt sustainability analysis, not a novelty in itself in Europe for the European Commission has performed this kind of analysis for many years (as acknowledged by Blanchard et al. themselves).

\section{Compliance and Enforcement, A Role for the European Parliament?}

The lack of compliance with EU fiscal rules has given rise to many Excessive Deficit Procedure (EDP) since 2003 when Germany and France had infringed the Stability and Growth Pact (SGP) thresholds. All EU-28 countries have undergone an EDP since the application of the SGP. The suspension of the SGP until 2022 does not ensure that fiscal rules' enforcement will improve in the future. On the one hand, EU countries will long be overwhelmed with high public debts, and the risk of rising bankruptcies and unemployment in 2021 and the coming years may keep on requiring fiscal stimuli. On the other hands, absent an upward reassessment of potential output in the EU, fiscal rules expressed in terms of cyclical adjustment will push for early recommendations of fiscal austerity that would act pro-cyclically, hurt the 
economy and certainly foster social unrest. Thus, a broader assessment of the appropriateness of the fiscal stance under the application of fiscal standards is appealing to escape a front-loading fiscal consolidation.

That said, the application of fiscal standards also raises the question of its enforcement and the institutions in charge of it. Blanchard et al. (2020) argue that two EU institutions could be eligible. According to them, the European Commission may see its role strengthened as regards the enforcement of fiscal rules that finally rests in the hands of the European Council, and be allowed to delay the adoption of non-complying national budgets. While the Commission has the technical skills for fiscal surveillance, it has not had so far the jurisprudence to act as an adjudicator. In contrast, the role of adjudicator naturally and usually falls to the Europe Court of Justice, which has the jurisprudence but lacks the technical skills to appreciate deviations from the standards. Finally, the European Fiscal Board (EFB) might apply but it shares similar characteristics with the Commission though it is independent from it (technical skills but no jurisprudence). Moreover, the EFB is only an advisory board on fiscal matters and would need to see its statutes revised to make it suitable for the control and enforcement of fiscal standards. While there are no easy options, those reported above would all require changes in hard law, i.e. modifications in European Treaties. This is not an insurmountable hurdle but it may further delay the adoption of fiscal standards.

Whatever the future conclusions of the EU revision of its fiscal framework (status quo, adoption of new rules, adoption of standards), immediate compliance and enforcement will be key to the success of the reform, not only at the general macroeconomic level (fiscal management in the EU must produce both macroeconomic stability and debt sustainability), but also for European public opinion.

Certainly, a European public opinion does not exist. Nevertheless, European public opinions have representatives: they are the Members of the European Parliament (MEP). Therefore, a non-binding modification of current EU legislation, a soft-law change, like the creation of a Fiscal Dialogue may be contemplated. It would consist in regular hearings of Ministers of Finance before the EP. Hallerberg et al. (2011) made a proposal in this spirit ten years ago. While reviewing the challenges of the European Semester at improving economic and fiscal surveillance in the EU and at promoting economic cooperation, they promoted the creation of regular Economic Dialogues on a legal basis close to that of Monetary Dialogues. These Economic Dialogues would give the EP "an important role as a forum for the exchange of information and a watchdog in the relationship between the Commission and the Council that would serve the purpose of increasing the European Semester's effectiveness and legitimacy". Their proposal did not lead to a concrete reform.

The current circumstances of renewed thinking about fiscal policies, frequent economic crises and rise of so-called "populism" give a new impetus for advocating a Fiscal Dialogue between different tiers of political authorities in the EU, including therefore its most democratic and European institution: the EP. In the following, I revisit the proposal by Hallerberg et al. (2011) but I argue a bit differently. A Fiscal Dialogue would not be enshrined in the European Semester and would be a complement to it. At a longer horizon, a successful Fiscal Dialogue procedure may well replace the European Semester and the SGP for the surveillance and control of fiscal 
policies. This is not its primary goal though, and existing procedures may continue in parallel. The primary goal of the Fiscal Dialogue would be to create the conditions for an enhanced and continuous coordination of fiscal and monetary policies in the EU throughout the year.

\section{Why a Fiscal Dialogue?}

There may be at least four important advantages with the creation of a Fiscal Dialogue.

First, it would offer an arena for a genuine European discussion of national fiscal policies before the representatives of European public opinions. Although the EP would not have power to delay the adoption of a national budget, the discussion may offer more transparency on the compliance of each government with the common rules or standards.

Second and maybe more importantly, the Fiscal Dialogue would offer some transparency on how each government considers the EU general context in the setting of its policies. Softer forms of cooperation might ensue from a better internalization of the European constraints. The single fact of having to talk to a European audience may change the stance of a national fiscal policy: it would be more difficult to choose a given policy and argue publicly that its consequences on the other member states is none of the business of the national Minister of Finance. Hence, the Fiscal Dialogue would tend to produce a better internalization of the spillovers of national fiscal policies on their partner countries, hence generating smooth and more effective fiscal coordination in the EU. In July 2020, the President of the ECB, Mrs. Christine Lagarde, has been very clear on the costs of negative spillovers on the proper functioning of the European monetary union: "we have seen (recently) the value of policies complementing each other rather than working against each other. A key shortcoming of the euro area during the sovereign debt crisis was its failure to consider the aggregate policy mix - that is, the negative spillovers created by uncoordinated fiscal policy tightening at a time when monetary policy was aiming to stimulate the economy. From 2013-18, fiscal policy in the euro area tightened by around 2.5 percentage points of GDP, compared with a loosening of around 0.8 percentage points in the USA. This was one factor behind the euro area's weak growth and inflation dynamics during that period. Now, policies are fully aligned in securing the fastest possible recovery, which also underpins medium-term price stability". (C. Lagarde, Europe's response to the crisis, ECB Blog, 23 July 2020, bold emphasis added) The academic literature has dealt with the spillovers of national fiscal policies in a monetary union and reached mixed results. Some papers found significant spillovers, mainly through trade linkages and when the fiscal shock originates in a large or neighbouring country (e.g. Beetsma et al. 2006; Bénassy-Quéré and Cimadomo 2006; Dabla-Norris et al. 2017), whereas some papers found negligible effects (e.g. Gros and Hobza 2001; Cwik and Wieland 2011; Attinasi et al. 2017). In a recent contribution, Devereux et al. (2020) developed a model incorporating international production network linkages. Then, they compare the simulation outcomes with models assuming that network linkages do not make a difference after an aggregate shock. They also compare with empirical estimates. They conclude that 
network linkages make a significant difference and give rise to simulation outcomes consistent with empirical estimates of the first group of papers. Fiscal spillovers matter in the euro area.

Third, a Fiscal Dialogue would give the EP a greater, though maybe symbolic, role and higher involvement in fiscal affairs that would reduce the criticism against technocracy and the possible misperception of the EP by voters. The latter may not fully understand the role of their representatives at the European Parliament in the overall setting of fiscal policies. They may be even inclined to think that they have a word in European fiscal affairs, though their role remains limited to the preparation, adoption and use of the European budget, only a tiny part of European-wide fiscal affairs, and to non-binding votes related to the European Semester. Public hearings would shed light precisely on the distinctive responsibilities of national Ministers of Finance and MEPs in the preparation and unfolding of national fiscal policies, while permitting Ministers of Finance to argue on their fiscal stance and debate with European representatives.

Fourth, to date, there is no regular public moment for a joint discussion of EU fiscal policies with the EP and the ECB, although there are four moments of that kind per year for discussion of EU monetary policies between the EP and the ECB, namely Monetary Dialogues. The quarterly hearings of the President of the ECB at the EP have their advantages and drawbacks (discussed recently by Claeys and DominguezJimenez 2020). As for its advantages, the Monetary Dialogue embodies ECB's concrete accountability and it offers an opportunity to MEPs to question the President of the ECB on past monetary policies, on the future strategy and on possible trade-offs between objectives (price stability, financial stability, recovery). The Monetary Dialogue is preceded by preparatory meetings with experts who have delivered policy briefs. These briefs on pre-defined topics give MEPs further insights on policymaking before they participate in the hearings. As for the drawbacks, the organization of the Monetary Dialogue permits too many MEPs to intervene. Thus, they ask very short questions to the ECB President, and too often, their questions are unrelated to the field of monetary policy and do not use the policy briefs that were prepared. Reforming the Monetary Dialogue may be on the agenda, to make it more effective for the sake of policy debate. In this respect, adopting a Fiscal Dialogue as a complement to the Monetary Dialogue may give a twofold impetus to transparency and democratic control on EU economic policies.

\section{Fiscal Dialogue: A (More) Concrete Proposal}

The Fiscal Dialogue may consist in quarterly hearings or testimonies of Ministers of Finance before the $\mathrm{EP}^{8}$. During the first hearing, Ministers of Finance would present their national Law of Finance, after the vote of national parliaments, and discuss how they fit in the domestic and European business cycles. The Ministers would provide arguments on policy objectives (growth, reduction in inequality, prospects for improved competitiveness, climate change mitigation, etc.), presenting economic

\footnotetext{
8 To facilitate the organization of four meetings per year and per country before the EP, some may not occur in plenary and may be limited to the Committee on Economic and Monetary Affairs of the EP.
} 
forecasts (GDP, inflation, trade balance, etc.), the underlying assumptions in the Law of Finance (e.g. on expected potential output, tax-base elasticities, fiscal multipliers, etc.), and the evolution of their public finances (overall deficit, interest payments, fiscal stance, etc.). They would certainly do so in a less technical manner than with the Commission, and they would include a discussion on the spillover effects of their policies and those from their partners'. Ministers would highlight the outcomes of ex-ante evaluation on new tax and fiscal measures on their objectives (via incentive and redistributive effects, employment effects, price effects, etc.). They would discuss the extent to which their policies would fit in general objectives of the EU (e.g. climate change mitigation, but also digitalization and internal cohesion). The main objective of this hearing would be to highlight enhanced fiscal coordination and accountability towards a democratic European institution. Domestic fiscal policies would tend to become public goods for the entire EU. This hearing may happen by the end of the calendar year, hence before the European Semester begins.

The second hearing may be devoted to the presentation of national debt sustainability analysis. Less oriented towards the short-run impact of the Law of finance on the real economy, this second hearing would help discuss the long-run impact of actual fiscal policy on debt sustainability (or stability). It would also highlight the possible deviations from the fiscal rules or standards and discuss about possible corrective policy actions. This hearing, say in March, would help share information on a better debt management across the EU Member States and would include a review of public spending, transfers and tax measures that would highlight the overall fiscal measures behind debt variations.

The third hearing would occur by the end of the European Semester, in June, and may give rise to joint discussion of European fiscal and monetary policies. The Monetary Dialogue in June may therefore become a joint Fiscal and Monetary Dialogue before the EP dedicated to a general discussion of the European policy mix. This event would have as a mere objective to enhance policy coordination between EU governments and the ECB - the policy mix in the EU would tend to become a public good in the EU-and to increase transparency towards the public.

The fourth hearing, in September, would be devoted to the presentation of Preparatory Law of Finance, hence before their vote at the national parliament. This hearing would share information on the shifts in the socio-economic framework that may have occurred since the previous Law of finance, it would highlight preliminary ex-post evaluations of the previous year's new tax and fiscal measures and it would expose the underlying assumptions of the incoming Law of Finance. Of course, the organization of the hearings in September and December will need adjustments to limit possible overlaps: underlying assumptions in the Preparatory and Final Laws of Finance may be very close. Indeed, they will, unless democratic controls at the national and European Parliaments produce some shifts in national fiscal policies. The September hearing would enhance ex-ante fiscal coordination, a quarter after an exchange of view with the ECB to facilitate coordination of fiscal and monetary policies, whereas the December hearing would reflect ex-post coordination (or deviations from an optimal policy that the testimony may help curb). 


\section{The Limits/Shortcomings of a Fiscal Dialogue}

The previous developments should not be overstated. There are only examples of what a Fiscal Dialogue may look like. The Fiscal Dialogue may well go deeper or simpler. The Fiscal Dialogue that I recommend may face many criticisms. I argue on a few here.

First, some of the above-mentioned proposals (mainly those regarding ex-antelexpost evaluations) may sound unrealistic for lack of statistical information in realtime. One may also argue that they may give an impetus for improving the availability of real-time information.

Second, general discussion on European fiscal policies, and maybe on their possible spillovers, may occur during Councils involving Ministers of Finance and during Eurogroup meetings. However, these discussions are neither public nor systematic. Discussions behind closed doors between Ministers of Finance could be complemented with public and transparent discussions before the European Parliament.

Third, the European Semester already provides a framework for the coordination of economic policies across the European Union. It allows EU countries to discuss their economic and budget plans and monitor progress at specific times throughout the year. However, the European Semester is mainly an exercise between two parts, a Member State and the Commission, until decisions are made on overall countryspecific recommendations at the Council. It does not involve directly the EU governments and the European Parliament ${ }^{9}$ and it is not a full ex-ante coordination device between all EU Member States.

Fourth, EU governments are already accountable towards their Parliament and are not accountable towards the European Parliament because tax and fiscal policies remain sovereign State policies. However, external fiscal spillovers may not be (sufficiently) accounted for in their accountability towards their own Parliament, and may therefore expose the entire area to unsatisfactory aggregate fiscal stances. The objective of the European Fiscal Board (EFB) is precisely to advise on the appropriate fiscal stance in the EU. While the National Fiscal Councils (NFC) monitor compliance with domestic fiscal rules in the Member States and thus enhance the internal accountability of governments, the EFB also cooperates with NFC to share best practices and common understanding on EU fiscal rules. It is not clear whether NFC have to discuss about EU economic spillovers of domestic policies. Moreover, NFC and EFB see their advisory role, and the ensuing aggregate fiscal stance, embedded in the EU fiscal framework that focuses on a complicated set of rules. Finally, fiscal accountability is blurred by the reliance on independent but technocratic institutions (members of EFB and NFB are nominated). In contrast, regular Fiscal Dialogues

\footnotetext{
9 The EP is involved in the European Semester when its ECON Committee prepares a report which is then voted in plenary and becomes an EP resolution on the European Semester for economic policy coordination. There are also non-binding votes on country-specific recommendations of the European Semester. Moreover and since 2012, there have been annual inter-parliamentary meetings between the EP and Members of National Parliaments. This is a forum for discussion on best practices about the implementation of the European Semester with a view to strengthening cooperation. In all cases, there are no direct relations between governments and the EP.
} 
at the EP would enhance accountability quite substantially. In the meantime, they may help governments better internalize EU spillovers and better cooperate at the EU level. Moreover, the ECB keeps its independence of means to pursue monetary policy despite the Monetary Dialogue. One may even argue that its independence is strengthened by its accountability. Sovereignty/independence and accountability are not mutually exclusive. Finally, EU governments have accepted some debt mutualisation in the Next Generation EU programme that may reveal some appetite for better cooperation that a Fiscal Dialogue is meant to foster.

Fifth, there are already many checks and balances to the use of fiscal tools in the EU. Beyond the SGP framework and the NFC and EFB mentioned above, the EU has set an Economic Dialogue. The Economic Dialogue is "held in order to enhance the dialogue between the EU institutions on the application of economic governance rules and with Member States, if appropriate, to ensure greater transparency and accountability". Actually, Economic Dialogues are mainly with the Commission and Eurogroup although there are also occasional exchanges of views with the Member States' finance ministers. Having a regular economic dialogue with Member States is problematic at the level of the EP which lacks legal competence in this regard. However, there are certain cases where there is a legal basis to invite Member States (e.g. euro area countries under enhanced surveillance following a macroeconomic adjustment programme or an excessive deficit procedure, macroeconomic imbalance procedure and other cases) but they remain highly specific and rare. Since its inception in 2012, there have been seventeen Economic Dialogues and five Exchanges of Views with a Minister of Finance involving fifteen EU Member States. Regular and structured Fiscal Dialogues would make a difference and increase transparency on European fiscal choices.

Last, there is a risk of "nationalization" of the debate in the EP. Opposition MEPs from a given country may engage in discussions with their Minister of Finance over issues which are rather of national and not European interest. This is a shortcoming that has already arisen during the Monetary Dialogue. Therefore, it would be key to organize Fiscal and Monetary Dialogues in a way to prevent national biases and highlight that MEPs represent the interests of all EU citizens. Although there may not be any perfect solution, members of the ECON Committee may play the role of an intermediary in collecting questions and reactions to the presentations of Ministers and help dampen the "nationalization" of policy debates.

\section{Precedents}

Although I have not found reference to a Fiscal Dialogue for the EU per se in the literature, I acknowledge that there have been earlier proposals for an improvement in the democratization of policy choices at the European level. I already mentioned the proposal by Hallerberg et al. (2011) of a regular Economic Dialogue, mimicking the Monetary Dialogue, to improve the effectiveness and legitimacy of the European Semester (see also Hallerberg et al. 2012). Let me mention a few more here. 
Andor et al. (2018) and Bouju et al. (2019) have promoted the creation of a Parliament limited to Euro area countries to foster fiscal cooperation ${ }^{10}$ and a new budget (with own resources) adopted by voluntary countries to meet future challenges (e.g. climate change and inequality mitigation). My proposal is much more limited as it does not require some changes in hard law. Meanwhile, it focuses on all EU countries, on regular meetings between governments and the EP, on EU fiscal spillovers to enhance macroeconomic management in Europe and on a closer and transparent coordination with the ECB via a joint annual Fiscal and Monetary Dialogue.

Watt (2005) promoted a reform of the Macroeconomic Dialogue for a better cooperation on fiscal and labour market issues at the EU level. Since its establishment in 1999, the Macroeconomic Dialogue remains a forum for informal, biannual discussions between policymakers from ECB, the Council, the Commission and the European social partners. Watt (2005) proposed that discussions on "facts" should give place to "a more policy-oriented debate towards consistent, quantitative development scenarios for the European economy as a whole, and its component countries, and about the mutually compatible actions by the actors concerned that are required to achieve them". While Watt enlarges the scope of EU coordination to social issues, its proposal does not involve governments and the European Parliament.

\section{Conclusion}

To sum up, this contribution has recalled that a regime of fiscal dominance does not lead to macroeconomic instability. After reviewing recent empirical results on fiscal sustainability, I concluded that sustainability was not a major concern for the EU in the short to mid-run.

Finally, I argue that Europeans should continue on the fiscal impetus they contributed to in 2020 by fostering coordination and transparency on EU fiscal policies. To achieve this objective, I revisit the idea of an enhanced dialogue on fiscal matters at the European Parliament and propose to establish a Fiscal Dialogue with the EU Member States. Although there are already (too many?) institutions that monitor the compliance of Member States with fiscal rules, I argue for more exchanges of views, on a regular basis, between Member States and their representatives at the European Parliament. In a move to combat both the discontent vis-à-vis politicians and the "scapegoating" of the EU in Member countries, a Fiscal Dialogue would give shared European flesh to domestically decided fiscal policies in the EU.

\footnotetext{
10 Hallerberg et al. (2012) have proposed that Members of the European Parliament from non-Euro area countries would not participate in (non-binding) votes on Euro area country-specific recommendations of the European Semester. Discussion would remain public but non-Euro are countries would not interfere in the vote.
} 


\section{References}

Ahmed, R., J. Aizenman, and Y. Jinjarak. 2021. Inflation and exchange rate targeting challenges under fiscal dominance. Journal of Macroeconomics, 67 (forthcoming).

Aldama, P., and J. Creel. 2020. Asymmetric macroeconomic stabilization and fiscal consolidation in the OECD and the Euro Area. OFCE Working Paper, 2020-09.

Andor, L., P. Berès, L. Bini Smaghi, L. Boone, S. Dullien, G. Duval, L. Garicano, M.A. Landesmann, G. Papaconstantinou, A. Roldan, G. Schick, X. Timbeau, A. Truger and S. Vallée. 2018. Blueprint for a Democratic Renewal of the Eurozone, Politico, 28 February.

Attinasi, M.G., M. Lalik, and I. Vetlov. 2017. Fiscal spillovers in the euro area a model-based analysis. ECB Working Paper 2040, March.

Auerbach, A.J., and Y. Gorodnichenko. 2012. Measuring the output responses to fiscal policy. American Economic Journal: Economic Policy 4(2): 1-27.

Beetsma, R., and M. Giuliodori. 2010. Fiscal adjustment to cyclical developments in the OECD: An empirical analysis based on real-time data. Oxford Economic Papers 62(3): 419-441.

Beetsma, R., M. Giuliodori, and F. Klaassen. 2006. Trade spill-overs of fiscal policy in the European Union: a panel analysis. Economic policy 21(48): 640-687.

Bénassy-Quéré, A. and J. Cimadomo. 2006. Changing patterns of domestic and cross-border fiscal policy multipliers in Europe and the US. CEPII Working Paper 2006-24, December.

Blanchard, O.J., A. Leandro and J. Zettelmeyer. 2020. Redesigning the EU fiscal rules: From rules to standards. Economic Policy (forthcoming).

Blanchard, O., and R. Perotti. 2002. An empirical characterization of the dynamic effects of changes in government spending and taxes on output. Quarterly Journal of Economics 117(4): 1329-1368.

Blanchard, O.J., and Lawrence H. Summers. 2020. Automatic stabilizers in a low-rate environment. American Economic Review Papers and Proceedings 110: 125-130.

Bohn, H. 1998. The Behavior of U. S. Public Debt and Deficits. Quarterly Journal of Economics 113(3): 949-963.

Bouju, M., L. Chancel, A.L. Delatte, S. Hennette, T. Piketty, G. Sacriste and A. Vauchez. 2019. Changer l'Europe, c'est possible !, Seuil.

Brunnermeier, M., Merkel, S., and Sannikov, Y. 2020. The fiscal theory of the price level with a bubble. Mimeo.

Canzoneri, M.B., R.E. Cumby, and B.T. Diba. 2001. Is the price level determined by the needs of fiscal solvency? American Economic Review 91(5): 1221-1238.

Checherita-Westphal, C. and V. Zdarek. 2017. Fiscal reaction function and fiscal fatigue: evidence for the euro area. ECB Working Paper, 2036, March.

Christ, C. 1968. A simple macroeconomic model with a government budget restraint. Journal of Political Economy 76(1): 53-67.

Cimadomo, J. 2012. Fiscal policy in real time. Scandinavian Journal of Economics 114: 440-465.

Claeys G. and M. Dominguez-Jimenez. 2020. How Can the European Parliament Better Oversee the European Central Bank?" Study for the Committee on Economic and Monetary Affairs, Policy Department for Economic, Scientific and Quality of Life Policies, European Parliament, Luxembourg.

Constâncio, V. 2020. The return of fiscal policy and the euro area fiscal rule. Comparative Economic Studies 62: 358-372.

Creel, J., E. Heyer, and M. Plane. 2011. Petit précis de politique budgétaire par tous les temps: Les multiplicateurs budgétaires au cours du cycle. Revue de l'OFCE 116(1): 61-88.

Creel, J., and H. Le Bihan. 2006. Using structural balance data to test the fiscal theory of the price level: Some international evidence. Journal of Macroeconomics 28: 338-360.

Cwik, T., and V. Wieland. 2011. Keynesian government spending multipliers and spillovers in the euro area. Economic Policy 26(67): 493-549.

Dabla-Norris, E., P. Dallari and T. Poghosyan. 2017. Fiscal spillovers in the euro area: Letting the data speak. IMF Working Paper No. 17/241.

Devereux M.D., K. Gente and C. Yu. 2020. Production networks and international fiscal spillovers. NBER Working Paper 28149.

El-Erian, M. 2017. The only game in town: Central Banks, instability and avoiding the next collapse. New York: Random House. 
Ferrari, A., and V. Nispi Landi. 2020. Whatever it takes to save the planet? Central banks and unconventional green policy. ECB Working Paper, 2500.

Gechert, S., and A. Rannenberg. 2018. Which fiscal multipliers are regime-dependent? A meta-regression analysis. Journal of Economic Surveys 32: 1160-1182.

Gros, D. and A. Hobza. 2001. Fiscal policy spillovers in the euro area: Where are they?" CEPS Working Document 176.

Hallerberg, M., B. Marzinotto and G.B. Wolff. 2011. How effective and legitimate is the European semester? Increasing the role of the European Parliament. Bruegel Working Paper, No. 2011/09.

Hallerberg, M., B. Marzinotto, and G.B. Wolff. 2012. An assessment of the European Semester. Study for European Parliament's Committee on Economic and Monetary Affairs.

Holston, K., T. Laubach, and J.C. Williams. 2017. Measuring the natural rate of interest: International trends and determinants. Journal of International Economics 108(1): S59-S75.

Leeper, E. 1991. Equilibria under 'active' and 'passive' monetary and fiscal policies. Journal of Monetary Economics 27(1): 129-147.

Poghosyan, T., and M.S. Tosun. 2019. Assessing activist fiscal policy in advanced and emerging market economies using real-time data. Oxford Economic Papers 71(1): 225-249.

Sargent, T. and N. Wallace. 1981. Some unpleasant monetarist arithmetic. FRB of Minneapolis Quarterly Review, 5.

Sims, C. 1994. A simple model for the study on the determination of the price level and the interaction of monetary and fiscal policy. Economic Theory 4: 381-399.

Watt, A. 2005. The coordination of economic policy in EMU: What contribution can the macroeconomic dialogue make to higher growth and employment? In Macroeconomic policy coordination in Europe and the role of the trade unions, ed. E. Hein, T. Niechoj, T. Schulten, and A. Truger, 237-259. Brussels: ETUI.

Wolf, M. 2012. Why quantitative easing is the only game in town. Financial Times, 15.

Woodford, M. 1995. Price-level determinacy without control of a monetary aggregate. Carnegie-Rochester Conference Series on Public Policy 43: 1-46.

Publisher's Note Springer Nature remains neutral with regard to jurisdictional claims in published maps and institutional affiliations. 